\title{
Electrospray Mass Spectrometric Detection of Neutral Metal Bipyridine Complexes Using Sodium Ions and Its Application in the Analysis of a Photochemical Ligand Substitution Reaction
}

\author{
Hisao HoRI*†, Jun ISHIHARA*, Kazuhide KOIKE*, Koji TAKeUCHI*, Takashi IBUSUKI*, \\ Junji TANABE $* *$ and Osamu ISHITANI**i \\ *National Institute for Resources and Environment, Onogawa, Tsukuba 305, Japan \\ **Graduate School of Science and Engineering, Saitama University, Shimo-Okubo, Urawa 338, Japan
}

\begin{abstract}
Sodium ions can be used as efficient chemical ionization agents in electrospray mass spectrometry of a wide variety of neutral metal bipyridine complexes. This ionization method was successfully permitted the identification of a neutral metal complex generated during the photochemical ligand substitution reaction: $\left[\operatorname{Re}(\text { bpy })(\mathrm{CO})_{3}\left\{\mathrm{P}(\mathrm{OEt})_{3}\right\}\right]^{+}+\mathrm{Cl}^{-} \rightarrow$ $\mathrm{Re}(\mathrm{bpy})(\mathrm{CO})_{2}\left\{\mathrm{P}(\mathrm{OEt})_{3}\right\} \mathrm{Cl}+\mathrm{CO}$ by sodium adduct formation to produce an electrospray-active species $\left[\mathrm{Re}(\mathrm{bpy})(\mathrm{CO})_{2}\left\{\mathrm{P}(\mathrm{OEt})_{3}\right\} \mathrm{Cl}+\mathrm{Na}\right]^{+}$.
\end{abstract}

Keywords Electrospray mass spectrometry, bipyridine, photochemical ligand substitution, neutral complex

Metal bipyridine complexes have received a great deal of attention because they show unique photo-associating properties such as photosensitization ${ }^{1}$ and photocatalysis. ${ }^{2}$ Another reason for the extensive interest in these complexes is their molecular recognizing ability. ${ }^{3}$ For example, a rhenium bipyridine complex $\mathrm{Re}$ (bpy) $(\mathrm{CO})_{3} \mathrm{Cl}$ (bpy=2,2'-bipyridine) acts as a $\mathrm{CO}_{2-}$ reduction photocatalyst ${ }^{2 \mathrm{a}, \mathrm{b}}$ and a ruthenium bipyridine complex functionalized calixarene acts as an anion receptor. ${ }^{3 \mathrm{~b}}$ Electrospray (ES) mass spectrometry is a powerful tool for easy and rapid identification of the ionic metal complexes in solution. ${ }^{4}$ A great advantage of this technique is its usefulness for examining labile metal complexes. Identification of unstable reaction products is possible by introduction of the reaction solution to the electrospray probe without any pretreatment. As for applications of ES-mass spectrometry to analyses of photoreactions of bipyridine complexes, Arakawa and co-workers extensively studied the photosubstitution of ruthenium bipyridine complexes ${ }^{5-7}$ and we also recently examined the intermediates of photochemical reduction of $\mathrm{CO}_{2}$ caused by a rhenium bipyridine complex. ${ }^{8,9}$ However, detection of bipyridine complexes by this technique is restricted to charged species in solution. In other words, neutral complexes, which have no charge, produce no peaks or only peaks corresponding to fragment species, giving less significant information about their masses. To ionize neutral metal complexes, Henderson and co-workers reported that the addition of silver ${ }^{10}$ or alkoxy ${ }^{11}$ ions to metal carbonyls can cause a strong signal assigned to adduct

$\doteqdot$ To whom correspondence should be addressed. species, i.e., $[\text { metal carbonyl }+\mathrm{Ag}]^{+}$or $[$metal carbonyl+OR] $]^{-}$on the ES-mass spectrum. This method might be applied to the ionization of some neutral bipyridine complexes, however, such ionization agents cause undesired redox reactions or ligand substitutions. For example, complexes having halogen ligands react with silver ions, resulting in the decomposition of the complexes. In the present study, we report that the addition of a small amount of sodium ions (less than the concentration of the complex) is quite effective for detection of many neutral metal bipyridine complexes by formation of electrospray-active species [neutral complex+Na] ${ }^{+}{ }^{12}$ Then, a successful application of this method to the analysis of photochemical ligand substitution reaction is described. Furthermore, applications of this method to other metal complexes and the ionization by other alkali metal ions are discussed.

\section{Experimental}

\section{Materials}

All reagents and solvents were of high purity and commercially available from Kanto Chemical Co. Inc. and Aldrich Chemical Company. 4,4'-Bis(trifluoromethyl)-2,2'-bipyridine was prepared according to the literature. ${ }^{13} \mathrm{Ru}\left\{(\mathrm{HOOC})_{2} \mathrm{bpy}\right\}_{2} \mathrm{Cl}_{2}$ and $\mathrm{Ru}$ $\left\{(\mathrm{HOOC})_{2} \text { bpy }\right\}_{2}(\mathrm{SCN})_{2}$ were provided from Kojima Chemicals Co. Other metal bipyridine complexes were prepared according to reported methods: $\operatorname{Re}(\mathrm{bpy})$ $(\mathrm{CO})_{3} \mathrm{CN},{ }^{14} \mathrm{Re}($ bpy $)(\mathrm{CO})_{3} \mathrm{Cl},{ }^{15} \mathrm{Re}($ bpy $)(\mathrm{CO}){ }_{3} \mathrm{Br},{ }^{16}$ $\mathrm{Re}(\mathrm{bpy})(\mathrm{CO})_{3} \mathrm{OCHO},{ }^{2 \mathrm{~b}} \mathrm{Ru}(\mathrm{bpy})_{2}(\mathrm{CN})_{2},{ }^{17} \mathrm{Mo}(\mathrm{bpy})-$ $(\mathrm{CO})_{4},{ }^{18} \mathrm{Cr}(\mathrm{bpy})(\mathrm{CO})_{4},{ }^{18}\left[\mathrm{Re}(\mathrm{bpy})(\mathrm{CO})_{3}\left\{\mathrm{P}(\mathrm{OEt})_{3}\right\}\right]-$ 
$\left[\mathrm{SbF}_{6}\right]_{.2 e}$ The preparation methods for $\mathrm{Re}\left(\mathrm{Me}_{2} \mathrm{bpy}\right)-$ $(\mathrm{CO})_{3} \mathrm{Cl}$ and $\operatorname{Re}\left\{\left(\mathrm{CF}_{3}\right)_{2} \mathrm{bpy}\right\}(\mathrm{CO})_{3} \mathrm{Cl}$ were almost identical with that of $\operatorname{Re}(\mathrm{bpy})(\mathrm{CO})_{3} \mathrm{Cl}$, except that the corresponding bipyridine derivatives were used. $\mathrm{Re}($ bpy $)(\mathrm{CO})_{3} \mathrm{OH}$ was prepared from a water complex $^{2 b}$, followed by the treatment with sodium hydroxide.

\section{ES-mass spectra measurements}

Positive ion ES-mass spectra were recorded on a Hitachi M-1200 mass spectrometer with an M-1206 electrospray probe operating at a needle voltage of 3 $\mathrm{kV}$. Nitrogen was used as the drying and nebulizing gas. Drift voltage was varied from 10 to $60 \mathrm{~V}$. A Hitachi L-6200 pump and mobile phase of methanol (HPLC grade) were used to deliver the sample solutions to the electrospray probe with a flow rate of 0.05

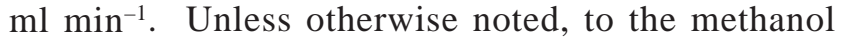
solution of each complex $(2 \mathrm{mM})$ was added the same volume of methanol solution of sodium nitrate $(1 \mathrm{mM})$, then the solution $(1 \mu \mathrm{l})$ was introduced into the electrospray probe through a Rheodyne 7125 injector.

\section{Results and Discussion}

ES-mass spectra for neutral rhenium bipyridine complexes with addition of sodium ions

Figure 1 shows the ES-mass spectra of $\operatorname{Re}(\mathrm{bpy})(\mathrm{CO})_{3^{-}}$ $\mathrm{CN}$ in methanol with addition of sodium ions. We used here sodium nitrate as the sodium ion source because the $\mathrm{NO}_{3}{ }^{-}$ion has very poor coordinating ability. In the absence of sodium ions, no peaks were detected at low drift voltages such as 10 to $20 \mathrm{~V}$. In contrast, addition of a small amount of sodium ions caused a large parent peak at $m / z=476$, corresponding to the mass number of $\left[\operatorname{Re}(\text { bpy })(\mathrm{CO})_{3} \mathrm{CN}+\mathrm{Na}\right]^{+}$(Fig. 1a). When the drift voltage was larger than $20 \mathrm{~V}$, an additional peak corresponding to a CO-loss species $\left[\operatorname{Re}(\mathrm{bpy})(\mathrm{CO})_{2} \mathrm{CN}+\mathrm{Na}\right]^{+}$ $(\mathrm{m} / \mathrm{z}=448)$ appeared (Fig. 1b,c). Figure 2 shows (a) observed and (b) calculated isotope distribution patterns of the peak at $m / z=476$, which was assigned to $\left[\mathrm{Re}(\mathrm{bpy})(\mathrm{CO})_{3} \mathrm{CN}+\mathrm{Na}\right]^{+}$. The observed pattern is in agreement with that of the calculated one, showing that the species is monovalent and that the structure of the species is undoubtedly $\left[\mathrm{Re}(\mathrm{bpy})(\mathrm{CO})_{3} \mathrm{CN}+\mathrm{Na}\right]^{+}$. Therefore, it is possible to know the molecular mass of the original neutral complex by subtracting the sodium mass from the observed $\mathrm{m} / \mathrm{z}$ value. Small peaks of sodium adducts were often observed in ES-mass spectra of neutral compounds containing oxygen ${ }^{19}$ or nitrogen atoms $\mathrm{s}^{4}$, where the sodium ions interact with the lone-pair electrons on these atoms of the compounds. For example, Borrett and co-workers reported that phosphoric acid forms 1:1 to 1:3 adducts with sodium ions. ${ }^{19}$ On the other hand, the neutral metal bipyridine complexes which have several carbonyl ligands presented here form only 1:1 adduct, even when the sodium ions are added in large excess. This observation
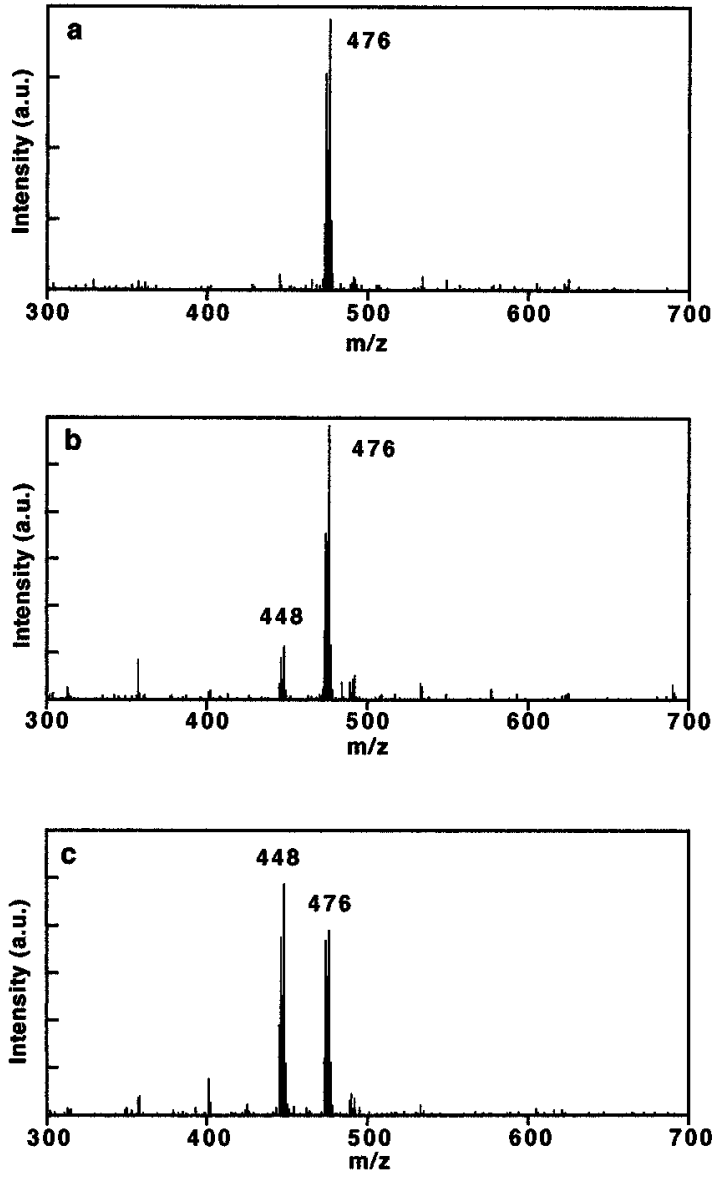

Fig. 1 ES-mass spectra of $\mathrm{Re}(\mathrm{bpy})(\mathrm{CO})_{3} \mathrm{CN}$ containing $\mathrm{NaNO}_{3}$ at drift voltages of (a) 20, (b) 40 and (c) $60 \mathrm{~V}$. To the methanol solution of $\operatorname{Re}(\mathrm{bpy})(\mathrm{CO})_{3} \mathrm{CN}(2 \mathrm{mM})$ was added the same volume of methanol solution of $\mathrm{NaNO}_{3}(1 \mathrm{mM})$ and then the mixed solution was introduced into the electrospray probe.
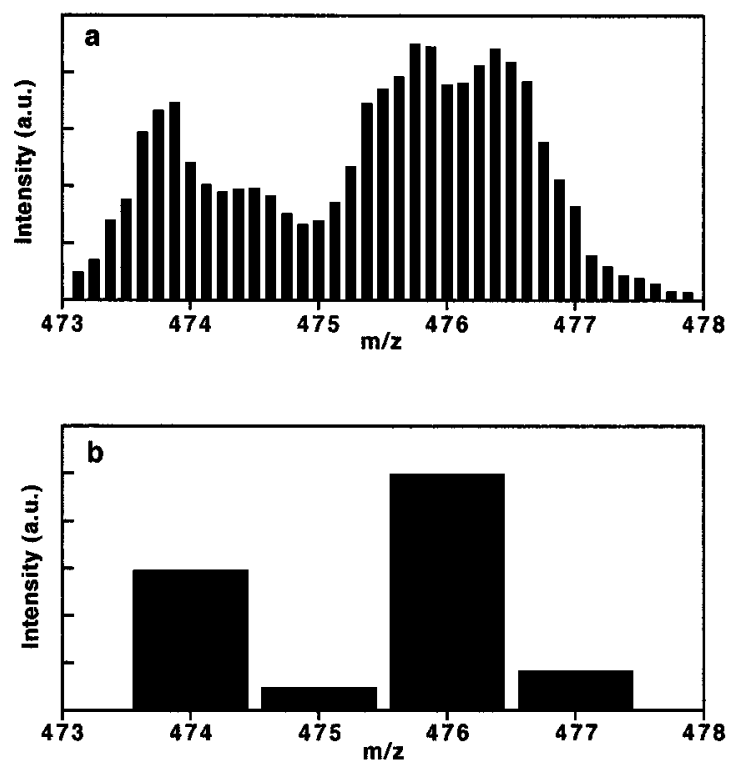

Fig. 2 Isotope distribution patterns for the peak assigned to $\left[\mathrm{Re}(\mathrm{bpy})(\mathrm{CO})_{3} \mathrm{CN}+\mathrm{Na}\right]^{+}$: (a) observed and (b) calculated. 
suggests that the sodium ion does not interact with the oxygen atoms of the bipyridine carbonyl complexes. Actually, no peak of $\left[\mathrm{Re}(\mathrm{CO})_{5} \mathrm{Cl}+\mathrm{Na}\right]^{+}$was observed for the solution of $\operatorname{Re}(\mathrm{CO})_{5} \mathrm{Cl}$ containing sodium ions, indicating that the sodium ions mainly interact with the $\pi$-electrons on the bipyridine ligand of the complexes.

Figure 3 shows the ES-mass spectra of $\operatorname{Re}($ bpy $)(\mathrm{CO})_{3-}$ $\mathrm{Cl}$ containing sodium ions. Although fragment peaks assigned to $\left[\operatorname{Re}(\mathrm{bpy})(\mathrm{CO})_{3}\right]^{+}(m / z=427)$ and $[\operatorname{Re}(\mathrm{bpy})-$ $\left.(\mathrm{CO})_{3}+\mathrm{MeOH}\right]^{+}(m / z=459)$ appeared, a large parent peak corresponding to $\left[\mathrm{Re}(\mathrm{bpy})(\mathrm{CO})_{3} \mathrm{Cl}+\mathrm{Na}\right]^{+}$ $(m / z=485)$ was clearly observed. For $\operatorname{Re}(b p y)(\mathrm{CO})_{3} \mathrm{Cl}$, a $\mathrm{Cl}^{-}$-loss species $\left[\operatorname{Re}(\text { bpy })(\mathrm{CO})_{3}\right]^{+}$was observed while a $\mathrm{CO}-$ loss species $\left[\operatorname{Re}(\text { bpy })(\mathrm{CO}){ }_{2} \mathrm{Cl}+\mathrm{Na}\right]^{+}$was not observed at relatively high drift voltages $(40-60 \mathrm{~V})$. On the contrary, a $\mathrm{CN}^{-}-$loss species $\left[\operatorname{Re}(\text { bpy })(\mathrm{CO})_{3}\right]^{+}$ was not observed while a CO-loss species $[\operatorname{Re}(b p y)-$ $\left.(\mathrm{CO})_{2} \mathrm{CN}+\mathrm{Na}\right]^{+}$was observed in the case of $\mathrm{Re}(\mathrm{bpy})-$ $(\mathrm{CO})_{3} \mathrm{CN}$ at the same drift voltages (vide supra). It is interesting to note that other ligand(s) can affect the release of the $\mathrm{CO}$ ligand of these complexes.

Application to monitoring of photochemical ligand substitution reaction

It has been known that some metal bipyridine and
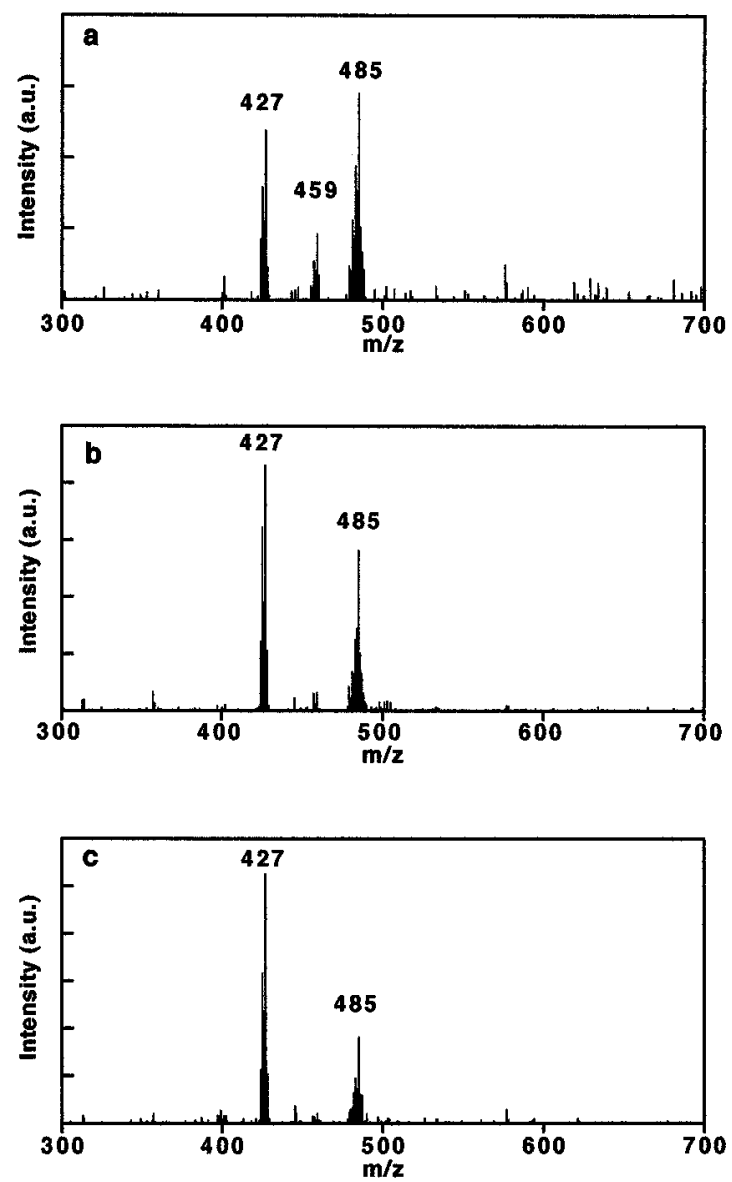

Fig. 3 ES-mass spectra of $\mathrm{Re}(\mathrm{bpy})(\mathrm{CO})_{3} \mathrm{Cl}$ containing $\mathrm{NaNO}_{3}$ at drift voltages of (a) 10, (b) 40 and (c) $60 \mathrm{~V}$. related complexes cause photochemical ligand substitution reactions..$^{5-9,20-25}$ Such reactions were traced using UV-vis spectra ${ }^{20,22,23,25}$, IR (including time-resolved techniques) ${ }^{21}$, and HPLC. ${ }^{9,24}$ ES-mass spectrometry has also become increasingly important as a method to study such reactions since Arakawa and co-workers elucidated the photosubstitution reactions of ruthenium diimine complexes. Although ES-mass spectrometry is useful for monitoring of photochemical ligand substitution reactions, the appearance or disappearance of neutral species could not be monitored. Therefore, we applied the method of sodium ion addition to examine the photosubstitution reaction of $\left[\mathrm{Re}(\mathrm{bpy})(\mathrm{CO})_{3}-\right.$ $\left.\left\{\mathrm{P}(\mathrm{OEt})_{3}\right\}\right]^{+}$with $\mathrm{Cl}^{-}$. When excess $\mathrm{NEt}_{4} \mathrm{Cl}$ was added to the acetone solution of this complex and then irradiated (365 nm light) under an argon atmosphere, the UV-vis absorption spectrum dramatically changed, accompanied with an isosbestic point (Fig. 4). The ESmass spectra of the solutions both before and after irradiation showed only peaks assigned to $\left[\operatorname{Re}(b p y)(\mathrm{CO})_{3}-\right.$ $\left.\left\{\mathrm{P}(\mathrm{OEt})_{3}\right\}\right]^{+}(m / z=593)$ and a fragment species $[\mathrm{Re}(\mathrm{bpy})-$ $\left.(\mathrm{CO})_{2}\left\{\mathrm{P}(\mathrm{OEt})_{3}\right\}\right]^{+}(\mathrm{m} / \mathrm{z}=565)$ without addition of sodium ions. On the other hand, addition of sodium ions to the reaction solution after irradiation caused another parent peak assigned to $\left[\mathrm{Re}(\mathrm{bpy})(\mathrm{CO})_{2}\left\{\mathrm{P}(\mathrm{OEt})_{3}\right\} \mathrm{Cl}\right.$ $+\mathrm{Na}]^{+}(m / z=623)$, as shown in Fig. 5b. Therefore, it is clear that the irradiation caused the substitution of the $\mathrm{CO}$ ligand of $\left[\operatorname{Re}(\text { bpy })(\mathrm{CO})_{3}\left\{\mathrm{P}(\mathrm{OEt})_{3}\right\}\right]^{+}$by a chloride ion to form neutral species $\mathrm{Re}(\mathrm{bpy})(\mathrm{CO})_{2}\left\{\mathrm{P}(\mathrm{OEt})_{3}\right\} \mathrm{Cl}$. In fact, the analytical data for the product isolated by silica-gel chromatography using dichloromethane/ ethyl acetate bore out this ligand substitution. Anal. Calcd. for $\mathrm{C}_{18} \mathrm{H}_{23} \mathrm{O}_{5} \mathrm{~N}_{2} \mathrm{PClRe}: \mathrm{C}, 36.03 ; \mathrm{H}, 3.86 ; \mathrm{N}$, 4.67. Found: C, 36.02; H, 3.90; N, 4.60. IR ( $v_{\mathrm{CO}} /$ $\left.\mathrm{cm}^{-1}, \mathrm{CH}_{2} \mathrm{Cl}_{2}\right)$ : 1936,1857 . When the complex

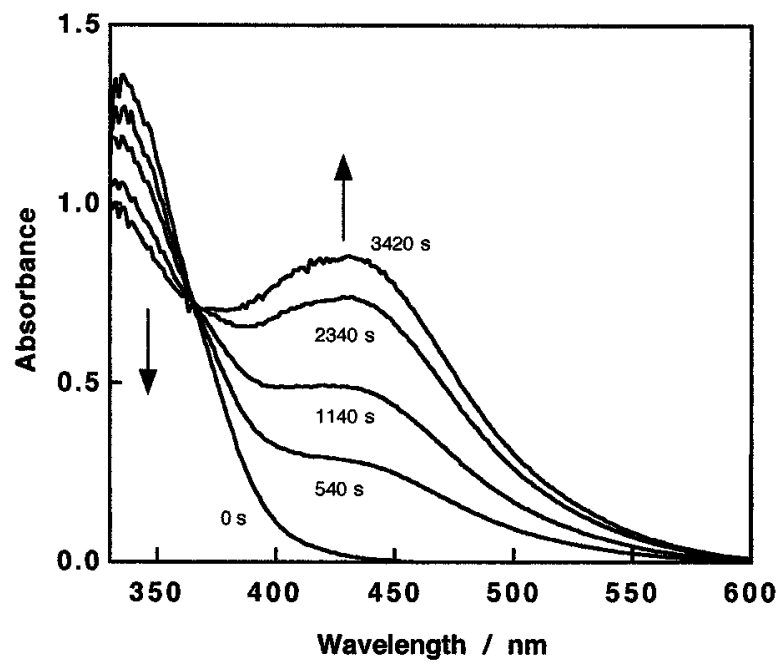

Fig. 4 UV-vis absorption spectral changes of an acetone solution containing $\left[\mathrm{Re}(\mathrm{bpy})(\mathrm{CO})_{3}\left\{\mathrm{P}(\mathrm{OEt})_{3}\right\}\right]^{+}\left(3.4 \times 10^{-4} \mathrm{M}\right)$ and $\mathrm{NEt}_{4} \mathrm{Cl}(1.5 \mathrm{mM})$ under an argon atmosphere during $365 \mathrm{~nm}$ irradiation up to $3420 \mathrm{~s}$. Light intensity was $2.35 \times 10^{-7}$ einstein $\mathrm{s}^{-1}$ ( 1 einstein $\approx 6.022 \times 10^{23}$ photons). 

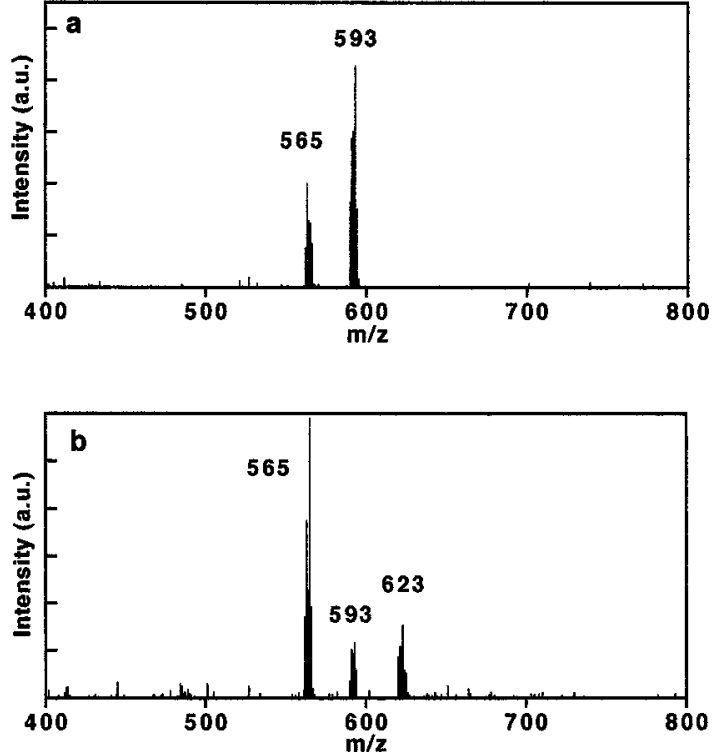

Fig. 5 Changes in ES-mass spectra due to irradiation. Drift voltage was $40 \mathrm{~V}$. An acetone solution containing [Re(bpy)$\left.(\mathrm{CO})_{3}\left\{\mathrm{P}(\mathrm{OEt})_{3}\right\}\right]^{+}\left(3.4 \times 10^{-4} \mathrm{M}\right)$ and $\mathrm{NEt}_{4} \mathrm{Cl}(1.5 \mathrm{mM})$ was irradiated $(365 \mathrm{~nm})$ under an argon atmosphere: (a) taken before irradiation; (b) taken after $3420 \mathrm{~s}$ irradiation with addition of the same volume of methanol solution of $\mathrm{NaNO}_{3}(1$ $\mathrm{mM})$ to the reaction solution.

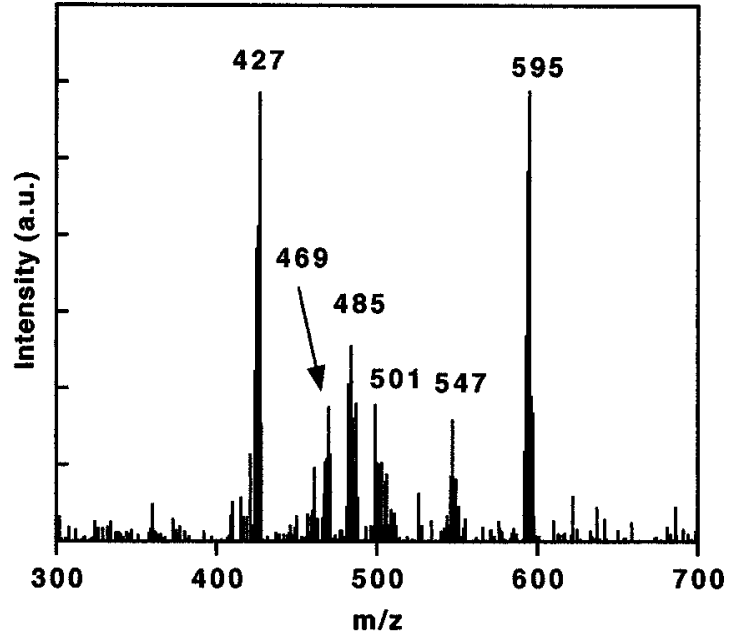

Fig. 6 ES-mass spectrum of $\operatorname{Re}($ bpy $)(\mathrm{CO})_{3} \mathrm{Cl}$ containing $\mathrm{Li}^{+}$, $\mathrm{K}^{+}, \mathrm{Na}^{+}, \mathrm{Rb}^{+}$, and $\mathrm{Cs}^{+}$ions. Drift voltage was $40 \mathrm{~V}$. To the methanol solution of $\operatorname{Re}($ bpy $)(\mathrm{CO})_{3} \mathrm{Cl}(2 \mathrm{mM})$ was added the same volume of methanol solution of each metal acetate (1 $\mathrm{mM}$ ). The $\mathrm{m} / \mathrm{z}$ values of $469,485,501,547$ and 595 are assigned to $\left[\mathrm{Re}(\mathrm{bpy})(\mathrm{CO})_{3} \mathrm{Cl}+\mathrm{Li}\right]^{+},\left[\mathrm{Re}(\mathrm{bpy})(\mathrm{CO})_{3} \mathrm{Cl}+\mathrm{Na}\right]^{+}$, $\left[\mathrm{Re}(\mathrm{bpy})(\mathrm{CO})_{3} \mathrm{Cl}+\mathrm{K}\right]^{+},\left[\operatorname{Re}(\mathrm{bpy})(\mathrm{CO})_{3} \mathrm{Cl}+\mathrm{Rb}\right]^{+}$and $[\mathrm{Re}(\mathrm{bpy})-$ $\left.(\mathrm{CO})_{3} \mathrm{Cl}+\mathrm{Cs}\right]^{+}$, respectively. The $\mathrm{m} / z$ value of 427 is assigned to a fragment ion $\left[\operatorname{Re}(\mathrm{bpy})(\mathrm{CO})_{3}\right]^{+}$.

Table 1 Electrospray mass spectral data for neutral metal complexes having bipyridine ligand(s) with addition of sodium ions

\begin{tabular}{|c|c|c|}
\hline Complex & $\begin{array}{l}\text { Drift voltage } \\
\qquad N\end{array}$ & Detected ions derived from the complex $(\mathrm{m} / \mathrm{z})^{\mathrm{a}}$ \\
\hline \multirow[t]{2}{*}{$\operatorname{Re}($ bpy $)(\mathrm{CO})_{3} \mathrm{CN}$} & $10-20$ & {$\left[\operatorname{Re}(\text { bpy })(\mathrm{CO})_{3} \mathrm{CN}+\mathrm{Na}\right]^{+}(476)$} \\
\hline & $40-60$ & {$\left[\operatorname{Re}(\text { bpy })(\mathrm{CO})_{3} \mathrm{CN}+\mathrm{Na}\right]^{+}(476),\left[\operatorname{Re}(\text { bpy })(\mathrm{CO})_{2} \mathrm{CN}+\mathrm{Na}\right]^{+}(448)$} \\
\hline \multirow[t]{2}{*}{$\operatorname{Re}($ bpy $)(\mathrm{CO})_{3} \mathrm{Cl}$} & $10-20$ & $\begin{array}{l}\left.\left[\operatorname{Re}(\text { bpy })(\mathrm{CO})_{3} \mathrm{Cl}+\mathrm{Na}\right]^{+}(485), \operatorname{Re}(\mathrm{bpy})(\mathrm{CO})_{3}\right]^{+}(427) \\
{\left[\operatorname{Re}(\mathrm{bpy})(\mathrm{CO})_{3}+\mathrm{MeOH}\right]^{+}(459)}\end{array}$ \\
\hline & $40-60$ & {$\left[\operatorname{Re}(\text { bpy })(\mathrm{CO})_{3} \mathrm{Cl}+\mathrm{Na}\right]^{+}(485),\left[\operatorname{Re}(\mathrm{bpy})(\mathrm{CO})_{3}\right]^{+}(427)$} \\
\hline $\operatorname{Re}($ bpy $)(\mathrm{CO})_{3} \mathrm{Br}$ & $10-60$ & {$\left[\operatorname{Re}(\text { bpy })(\mathrm{CO})_{3} \mathrm{Br}+\mathrm{Na}\right]^{+}(529),\left[\operatorname{Re}(\mathrm{bpy})(\mathrm{CO})_{3}\right]^{+}(427)$} \\
\hline $\mathrm{Re}(\mathrm{bpy})(\mathrm{CO})_{3} \mathrm{OCHO}$ & $10-60$ & {$\left[\mathrm{Re}(\mathrm{bpy})(\mathrm{CO})_{3} \mathrm{OCHO}+\mathrm{Na}\right]^{+}(495),\left[\operatorname{Re}(\mathrm{bpy})(\mathrm{CO})_{3}\right]^{+}(427)$} \\
\hline $\operatorname{Re}(\mathrm{bpy})(\mathrm{CO})_{3} \mathrm{OH}$ & 10 & {$\left[\operatorname{Re}(\text { bpy })(\mathrm{CO})_{3} \mathrm{OMe}+\mathrm{Na}\right]^{+}(481),\left[\operatorname{Re}(\mathrm{bpy})(\mathrm{CO})_{3}\right]^{+}(427)$} \\
\hline \multirow[t]{2}{*}{$\operatorname{Re}\left(\mathrm{Me}_{2}\right.$ bpy $)(\mathrm{CO})_{3} \mathrm{Cl}$} & 10 & $\begin{array}{l}{\left[\mathrm{Re}(\mathrm{Me} 2 \mathrm{bpy})(\mathrm{CO})_{3} \mathrm{Cl}+\mathrm{Na}^{+}(513),\left[\operatorname{Re}\left(\mathrm{Me}_{2} \mathrm{bpy}^{+}(\mathrm{CO})_{3}\right]^{+}(455),\right.\right.} \\
{\left[\operatorname{Re}\left(\mathrm{Me}_{2} \mathrm{bpy}\right)(\mathrm{CO})_{3}+\mathrm{MeOH}\right]^{+}(487)}\end{array}$ \\
\hline & $20-60$ & {$\left[\operatorname{Re}\left(\mathrm{Me}_{2} \mathrm{bpy}\right)(\mathrm{CO})_{3} \mathrm{Cl}+\mathrm{Na}\right]^{+}(513),\left[\operatorname{Re}\left(\mathrm{Me}_{2} \mathrm{bpy}\right)(\mathrm{CO})_{3}\right]^{+}(455)$} \\
\hline $\operatorname{Re}\left\{\left(\mathrm{CF}_{3}\right)_{2} \mathrm{bpy}\right\}(\mathrm{CO})_{3} \mathrm{Cl}$ & $10-60$ & {$\left[\operatorname{Re}\left\{(\mathrm{CF} 3)_{2} \mathrm{bpy}\right\}(\mathrm{CO})_{3} \mathrm{Cl}+\mathrm{Na}\right]^{+}(621),\left[\operatorname{Re}\left\{\left(\mathrm{CF}_{3}\right)_{2} \mathrm{bpy}\right\}(\mathrm{CO})_{3}\right]^{+}(563)$} \\
\hline $\operatorname{Re}($ bpy $)(\mathrm{CO})_{2}\left\{\mathrm{P}(\mathrm{OEt})_{3}\right\} \mathrm{Cl}$ & $10-60$ & {$\left[\operatorname{Re}(\right.$ bpy $\left.)(\mathrm{CO})_{2}\left\{\mathrm{P}(\mathrm{OEt})_{3}\right\} \mathrm{Cl}+\mathrm{Na}\right]+(623),\left[\operatorname{Re}(\mathrm{bpy})(\mathrm{CO})_{2}\left\{\mathrm{P}(\mathrm{OEt})_{3}\right\}\right]^{+}(565)$} \\
\hline $\operatorname{Re}(\mathrm{CO})_{5} \mathrm{Cl}$ & $10-60$ & n.d. \\
\hline $\mathrm{Ru}(\mathrm{bpy})_{2}(\mathrm{CN})_{2}$ & $10-60$ & {$\left[\mathrm{Ru}(\mathrm{bpy})_{2}(\mathrm{CN})_{2}+\mathrm{Na}\right]^{+}(489)$} \\
\hline $\mathrm{Ru}\left\{(\mathrm{HOOC})_{2} \mathrm{bpy}\right\}_{2} \mathrm{Cl}_{2}$ & $10-60$ & n.d. \\
\hline $\mathrm{Ru}\left\{(\mathrm{HOOC})_{2} \mathrm{bpy}\right\}_{2}(\mathrm{SCN})_{2}$ & $10-60$ & n.d. \\
\hline \multirow[t]{2}{*}{$\mathrm{Mo}(\mathrm{bpy})(\mathrm{CO})_{4}$} & 10 & n.d. \\
\hline & $40-60$ & {$\left[\mathrm{Mo}(\text { bpy })(\mathrm{CO})_{3}+\mathrm{Na}\right]^{+}(361)$} \\
\hline \multirow[t]{2}{*}{$\mathrm{Cr}(\mathrm{bpy})(\mathrm{CO})_{4}$} & 10 & n.d. \\
\hline & 40 & {$\left[\mathrm{Cr}(\mathrm{bpy})(\mathrm{CO})_{3}+\mathrm{Na}\right]^{+}(315),\left[\mathrm{Cr}(\mathrm{bpy})(\mathrm{CO})_{2}+\mathrm{Na}\right]^{+}(287)$} \\
\hline
\end{tabular}

a. Species are identified by the peak of greatest intensity in the isotope distribution pattern.

$\left[\mathrm{Re}(\mathrm{bpy})(\mathrm{CO})_{3}\left\{\mathrm{P}(\mathrm{OEt})_{3}\right\}\right]^{+}$containing excess $\mathrm{NEt}_{4} \mathrm{Cl}$ was irradiated in acetonitrile instead of acetone, the peak assigned to $\left[\operatorname{Re}(\mathrm{bpy})(\mathrm{CO})_{2}\left\{\mathrm{P}(\mathrm{OEt})_{3}\right\} \mathrm{Cl}+\mathrm{Na}\right]^{+}$did not appear even when the sodium ions were added, and a large peak for $\left[\operatorname{Re}(\text { bpy })(\mathrm{CO})_{2}\left\{\mathrm{P}(\mathrm{OEt})_{3}\right\}(\mathrm{MeCN})\right]^{+}$ $(\mathrm{m} / \mathrm{z}=606)$ was observed, indicating that acetonitrile predominantly reacts with the complex in this condition. In this manner, ligand substitutions were easily monitored by ES-mass spectrometry and the effectiveness of the ionization using sodium ions was demonstrated. 
Applications of this method to a wide variety of neutral metal bipyridine complexes and its limitations

The results of sodium ion addition to neutral $\mathrm{Re}, \mathrm{Ru}$, $\mathrm{Mo}$, and $\mathrm{Cr}$ complexes involving bipyridine and its derivatives $4,4^{\prime}-X_{2}-2,2^{\prime}$-bipyridine $\left(X_{2}\right.$ bpy; $X=M e, C F_{3}$, $\mathrm{COOH}$ ) are summarized in Table 1 . All of the rhenium complexes containing bipyridine gave large peak(s) assigned to the sodium adduct(s) of parent and/or fragment species. Some bipyridine complexes containing metals other than rhenium also produced the peaks of their sodium adducts. However, several complexes gave only insufficient peaks. For example, no peaks of the sodium adducts were detected for $\mathrm{Mo}(\mathrm{bpy})(\mathrm{CO})_{4}$ and $\mathrm{Cr}(\mathrm{bpy})(\mathrm{CO})_{4}$ at a low drift voltage. Only the sodium adducts of their CO-loss species, which may be produced by a vapor phase reaction of CO-loss species of the metal complexes with a sodium ion after vaporization in the electrospray probe, were observed at higher voltages such as 40 to $60 \mathrm{~V}$. Furthermore, complexes having carboxyl groups, i.e., $\mathrm{Ru}\left\{(\mathrm{HOOC})_{2-}\right.$ bpy $\}_{2} \mathrm{X}_{2}(\mathrm{X}=\mathrm{Cl}, \mathrm{SCN})$, caused no peaks. When $\mathrm{Re}(\mathrm{bpy})(\mathrm{CO})_{3} \mathrm{Cl}$ was dissolved in acetone or acetonitrile instead of methanol, the results were almost the same as those in methanol. On the other hand, when dimethylformamide (DMF) was used, sodium ions preferentially reacted with $\mathrm{DMF}$ to produce $[\mathrm{DMF}+\mathrm{Na}]^{+}$ $(m / z=96)$ and $[2 \mathrm{DMF}+\mathrm{Na}]^{+}(m / z=169)$, showing no signal of $\left[\mathrm{Re}(\text { bpy })(\mathrm{CO})_{3} \mathrm{Cl}+\mathrm{Na}\right]^{+}$. Even when methanol was used, $\mathrm{Re}(\mathrm{bpy})(\mathrm{CO})_{3} \mathrm{OH}$ produced the peak assigned to a methoxy complex $\left[\operatorname{Re}(b p y)(\mathrm{CO})_{3}{ }^{-}\right.$ $\mathrm{OMe}+\mathrm{Na}]^{+}$instead of $\left[\mathrm{Re}(\mathrm{bpy})(\mathrm{CO})_{3} \mathrm{OH}+\mathrm{Na}\right]^{+}$. Therefore, the selection of the solvent is important in this ionization method.

\section{Ionization by other alkali metal ions}

As described above, it is supposed that the sodium ion interacts with the bipyridine ligand of the complexes for the adduct formation. Such interaction may also occur for other alkali metal ions. Figure 6 shows the ES-mass spectra of $\mathrm{Re}(\mathrm{bpy})(\mathrm{CO})_{3} \mathrm{Cl}$ with addition of a mixed solution of $\mathrm{Li}, \mathrm{K}, \mathrm{Na}, \mathrm{Rb}$ and $\mathrm{Cs}$ acetates (some nitrates are insoluble in methanol, therefore acetates were used here). Each alkali metal ion caused the corresponding adduct peak and the cesium ion gave a larger adduct peak $(m / z=595)$ than those by other ions. Although cesium acetate is strongly hygroscopic, it could be used as an effective ionization agent if the samples cause no side reactions.

In conclusion, we presented here a new detection method in ES-mass spectrometry for neutral metal bipyridine complexes and applied it to the analysis of a photochemical ligand substitution reaction. Ionization by sodium ions is milder and therefore rarely cause ligand substitutions or redox reactions with active samples. The presence of a bipyridine ligand in complexes is required for this detection method, indicating that the sodium ion presumably interacts with the bipyridine ligand for the adduct formation. Further applications to identification of neutral species containing bipyridine ligand in photo- or electrochemical reactions are possible and desired.

The authors thank Kojima Chemicals Co. for providing the ruthenium complexes $\mathrm{Ru}\left\{(\mathrm{HOOC})_{2} \mathrm{bpy}\right\}_{2} \mathrm{Cl}_{2}$ and $\mathrm{Ru}\left\{(\mathrm{HOOC})_{2}-\right.$ bpy $\}_{2}(\mathrm{SCN})_{2}$.

\section{References}

1. (a) K. Kalyanasundaram, "Photochemistry of Polypyridine and Porphyrin Complexes", Academic Press, London, 1992. (b) K. Kalyanasundaram and M. Grätzel, "Photosensitization and Photocatalysis Using Inorganic and Organometallic Compounds", Kluwer Academic Publishers, Dordrecht, 1993. (c) B. O'Regan and M. Grätzel, Nature [London], 353, 737 (1991).

2. (a) J. Hawecker, J.- M. Lehn and R. Ziessel, J. Chem. Soc., Chem. Commun., 1983, 536. (b) J. Hawecker, J.- M. Lehn and R. Ziessel, Helv. Chim. Acta, 69, 1990 (1986). (c) O. Ishitani, I. Namura, S. Yanagida and C. Pac, J. Chem. Soc., Chem. Commun., 1987, 1153. (d) O. Ishitani, M. W. George, T. Ibusuki, F. P. A. Johnson, K. Koike, K. Nozaki, C. Pac, J. J. Turner and J. R. Westwell, Inorg. Chem., 33, 4712 (1994). (e) H. Hori, F. P. A. Johnson, K. Koike, O. Ishitani and T. Ibusuki, J. Photochem. Photobiol., A: Chem., 96, 171 (1996).

3. (a) P. D. Beer, Adv. Inorg. Chem., 39, 79 (1992). (b) P. D. Beer, Z. Chen, A. J. Goulden, A. Grieve, D. Hesek, F. Szemes and T. Wear, J. Chem. Soc., Chem. Commun., 1994, 1269. (c) P. D. Beer, M. G. B. Drew, D. Hesek, M. Shade and F. Szemes, Chem. Commun., 1996, 2161.

4. R. Colton, A. D'Agostino and J. C. Traeger, Mass Spectrom. Rev., 14, 79 (1995).

5. R. Arakawa, S. Tachiyashiki and M. Matsuo, Anal. Chem., 67, 4133 (1995).

6. R. Arakawa, L. Jian, A. Yoshimura, K. Nozaki, T. Ohno, H. Doe and T. Matsuo, Inorg. Chem., 34, 3874 (1995).

7. R. Arakawa, S. Mimura, G. Matsubayashi and T. Matsuo, Inorg. Chem., 35, 5725 (1996).

8. H. Hori, O. Ishitani, K. Koike, K. Takeuchi and T. Ibusuki, Anal. Sci., 12, 587 (1996).

9. H. Hori, F. P. A. Johnson, K. Koike, K. Takeuchi, T. Ibusuki and O. Ishitani, J. Chem. Soc., Dalton Trans., 1997, 1019.

10. W. Henderson and B. K. Nicholson, J. Chem. Soc., Chem. Commun., 1995, 2531.

11. W. Henderson, J. S. McIndoe, B. K. Nicholson and P. J. Dyson, Chem. Commun., 1996, 1183.

12. A preliminary account of some of the results has been reported: H. Hori, J. Ishihara, K. Koike, K. Takeuchi, T. Ibusuki and O. Ishitani, Chem. Lett., 1997, 273.

13. M. Furue, K. Maruyama, T. Oguni, M. Naiki and M. Kamachi, Inorg. Chem., 31, 3792 (1992).

14. K. Kalyanasundaram, M. Grätzel and M. K. Nazeeruddin, Inorg. Chem., 31, 5243 (1992).

15. J. V. Casper and T. J. Meyer, J. Phys. Chem., 87, 952 (1983).

16. C. Kutal, M. A. Weber, G. Ferraudi and D. Geiger, Organometallics, 4, 2161 (1985).

17. J. P. Collin and J. P. Sauvage, Inorg. Chem., 25, 135 (1986).

18. M. H. B. Stiddard, J. Chem. Soc., 4, 4712 (1962). 
19. V. T. Borrett, R. Colton and J. C. Traeger, Eur. Mass Spectrom., 1, 131 (1995).

20. M. S. Wrighton and D. L. Morse, J. Organomet. Chem., 97, 405 (1975).

21. I. G. Virrels, M. W. George, J. J. Turner, J. Peters and A. Vlcek, Jr., Organometallics, 15, 4089 (1996).

22. R. J. Shaver and D. P. Rillema, Inorg. Chem., 31, 4101 (1992).

23. D. P. Summers, J. C. Luong and M. S. Wrighton, J. Am.
Chem. Soc., 103, 5238 (1981).

24. C. Pac, S. Kaseda, K. Ishii and S. Yanagida, J. Chem. Soc., Chem. Commun., 1991, 787.

25. B. Durham, J. V. Caspar, J. K. Nagle and T. J. Meyer, J. Am. Chem. Soc., 104, 4803 (1982).

(Received October 22, 1997)

(Accepted January 23, 1998) 